\title{
UROLOGICAL PROBLEMS IN CHILDREN WITH SPINA BIFIDA CYSTICA AND SACRAL DEFECTS
}

\author{
By Kazuoki MiYazaKi \\ Department of Urology, Kanagawa Children's Medical Center, \\ Yokohama, fapan
}

THE incidence of spina bifida cystica per I000 live births in Europe and the United States has been reported, from 2 to 4 cases, as shown in Table I. In Japan its incidence has been much less than that of other countries, namely about 2 cases per I0,000 live births. Therefore, in the past, sufficient attention to this congenital anomaly had not been paid in our country, particularly the clinical control of the urological problems in these children tended to be overlooked.

\section{TABLE I}

Incidence of Spina Bifida Cystica per I000 Live Births

$\begin{array}{lllll}\text { Malpas } & \text { I937 } & \text { Liverpool } & \text { England } & \mathbf{2} \cdot 8 \\ \text { Record \& McKeown } & \text { I940 } & \text { Birmingham } & \text { England } & 3 \cdot 35 \\ \text { Coffey \& Jessop } & \text { I955 } & \text { Dublin } & \text { Eire } & 4 \cdot 2 \\ \text { MacCarthy \& Lindsay } & \text { I957 } & \text { Buckinghamshire } & \text { England } & \mathbf{2} \cdot 8 \\ \text { Harrer } & \text { I9I6 } & \text { New York } & \text { U.S.A. } & \text { I·I } \\ \text { Harris \& Steinberg } & \text { I954 } & \text { Rochester } & \text { U.S.A. } & \mathbf{2 \cdot 4} \\ \text { Ingalls } \text { et. al. } & \text { I956 } & \text { Rhode Island } & \text { U.S.A. } & \mathbf{2} \cdot 53 \\ \text { Ingraham \& Fowler } & \text { I956 } & \text { New England } & \text { U.S.A. } & \mathbf{2 \cdot 5} \\ \text { Mitani } & \text { I943 } & \text { Tokyo } & \text { Japan } & 0 \cdot 22 \\ \text { Neel } & \text { I958 } & \text { Hiroshima, Nagasaki, Kure } & \text { Japan } & 0 \cdot 20\end{array}$

But now a number of these children, who would have died of renal damage or meningeal infection in the past, are surviving, partly because of the progress in the neurosurgical approach, and antibiotic medication. According to the fact, many problems, such as more adequate medical care, habilitation and adaptation to social community are being recognised as keen topics.

In the past two years, 4I cases of spina bifida cystica and 7 cases of sacral defect were observed in our clinic.

Figure I illustrates the level of the radiological defect in the vertebral lamina classified in two groups. Twenty-four cases (58.5 per cent.) demonstrated lumbosacral defects (below L 3 ), and I7 cases (4I.5 per cent.) showed sacral or sacrococcygeal lesions. No case who had lesion above LI was found.

This fact may suggest that the cervical or thoracic lesions which were reported by many authors in other countries would be extremely rare in Japan. It could also be noted that the congenital sacral agenesis or sacral defect are to be relatively frequent in our country.

It is reasonable that $\mathrm{I} 4$ cases out of 48 who have lower vertebral anomalies can walk without difficulty and orthopaedical problems, because their lesions localise only in sacral segment. On the contrary, 46 cases ( 95.8 per cent.) in this 


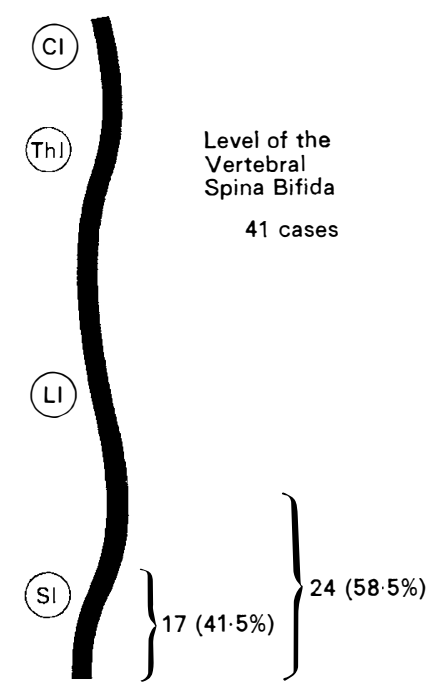
Fig. r.-Level of the verte-
bral spina bifida.

Fig. 2.-Effects on residual urine by bladder training (credé manoeuvre) in spina bifida bladder.

FIG. I

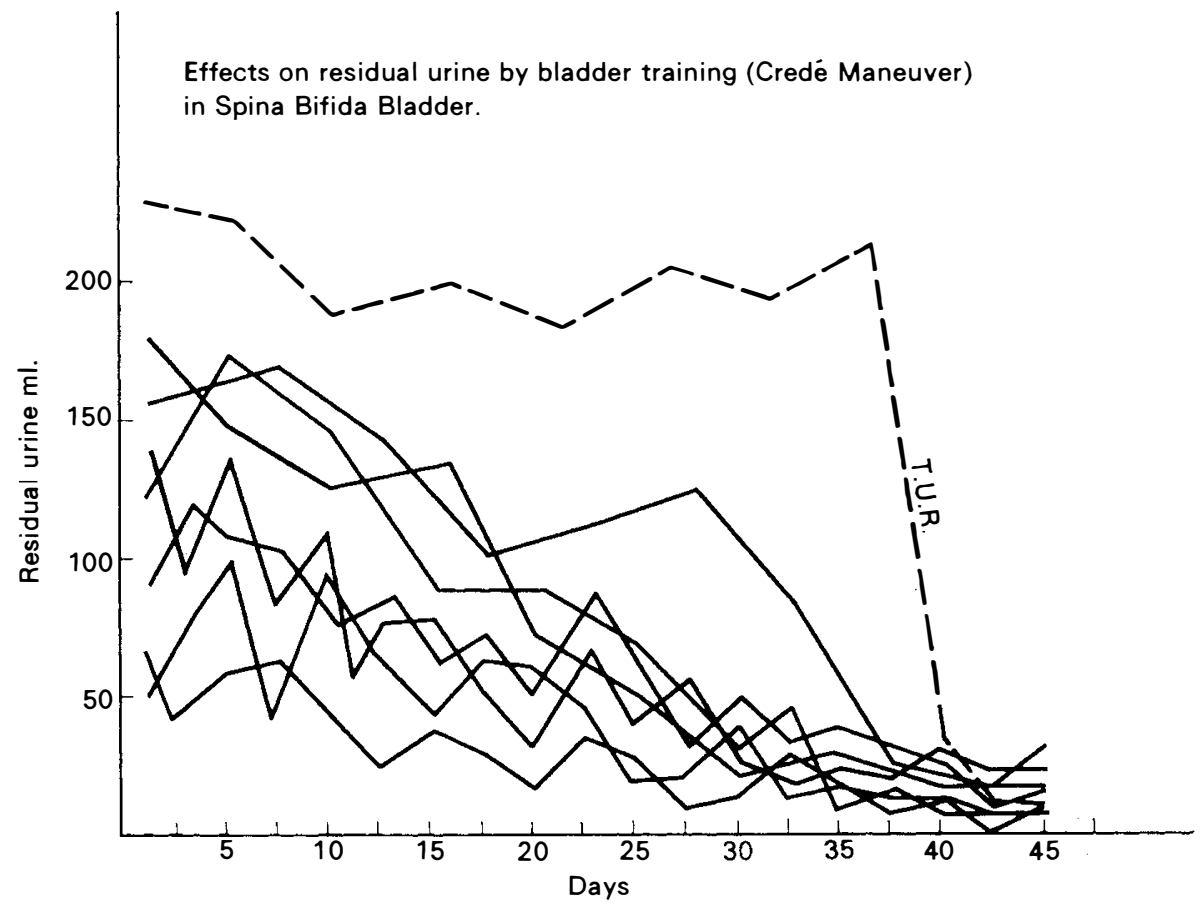

FIG. 2

series have urological problems such as urinary incontinence, fever attack and so on. Persistent urinary infection revealed in 53.7 per cent. of spina bifida cystica, and in $57^{\circ}$ I per cent. of sacral defects.

Vesico-ureteral refluxes are predominant in the group of the congenital 
sacral defects, predisposing the sacral nerve lesion to afflict the lower urinary tracts (Table II).

TABLE II

Urological Complications in Spina Bifida Cystica and Congenital Sacral Defect (48 Cases)

\begin{tabular}{|c|c|c|c|c|}
\hline & $\begin{array}{c}\text { Neurogenic } \\
\text { disturbance } \\
\text { of urination }\end{array}$ & $\begin{array}{c}\text { Urinary } \\
\text { infection }\end{array}$ & $\begin{array}{c}\text { Vesico- } \\
\text { ureteral } \\
\text { reflux }\end{array}$ & Hydronephrosis \\
\hline $\begin{array}{c}\text { Spina } \\
\text { bifida } \\
\text { cystica }\end{array}$ & $\begin{array}{c}37(4 \mathrm{I}) \\
(90.2 \%)\end{array}$ & $\begin{array}{c}22 \\
(53 \cdot 7 \%)\end{array}$ & $\begin{array}{c}\mathrm{II} \\
(25 \cdot 4 \%)\end{array}$ & $\begin{array}{c}8 \\
(19.5 \%)\end{array}$ \\
\hline $\begin{array}{c}\text { Congenital } \\
\text { sacral } \\
\text { defect }\end{array}$ & $\begin{array}{c}6(7) \\
(85.6 \%)\end{array}$ & $\begin{array}{c}4 \\
(57 \cdot \mathrm{I} \%)\end{array}$ & $\begin{array}{c}5 \\
(7 \mathrm{I} \cdot 4 \%)\end{array}$ & $\begin{array}{c}5 \% \\
(0 \%)\end{array}$ \\
\hline
\end{tabular}

\section{CLINICAL EXAMINATIONS}

In the newborn infant, the clinical evaluation of the neurological lesion is difficult. Skin sensation should be examined frequently. Urinary dribbling, continuous wetness of diaper, expressibility of the bladder and decrease in anal sphincter tone are the most important information to the bladder paralysis.

It is possible to detect the urinary infection and to estimate the bladder function by measurement of the residual urine volume and urinalysis.

Intravenous urography, retrograde cystography, especially descending cystourethrography, may help to form an impression about the types of bladder function and reactive status of posterior urethra. Particular attention should be paid to the trabeculation of bladder, vesico-ureteral reflux and appearance of posterior urethra, because they offer the important points to evaluate the urethral resistance (figs. 3, 4, and 5).

In order to obtain more precise information about bladder function, we are used to record the electro-manometric cystometrogram through a transurethral fine tube. It helps to distinguish the detrusor contraction between hypotonic and normotonic or hypertonic, though the normotonic pressure indicates some range of variations (figs. 6,7 and 8).

According to these informations the neurogenic bladders with spina bifida cystica were classified in grouping of lumbo-sacral lesion and sacral lesion (Table III).

In the sacral lesion group, 13 cases $(76.5$ per cent.) are hypotonic autonomous type, and 8 cases $(42 \cdot 1$ per cent.) belong to hypotonic autonomous bladder in the lumbo-sacral group. Only one case of typical hypertonic spastic bladder was found in the lumbo-sacral lesion group.

In each group, about one half of the cases were observed to have the sphincteric resistance producing a large amount of residual urine, on which the manual expression to obtain urinary stream was unsuccessful. 


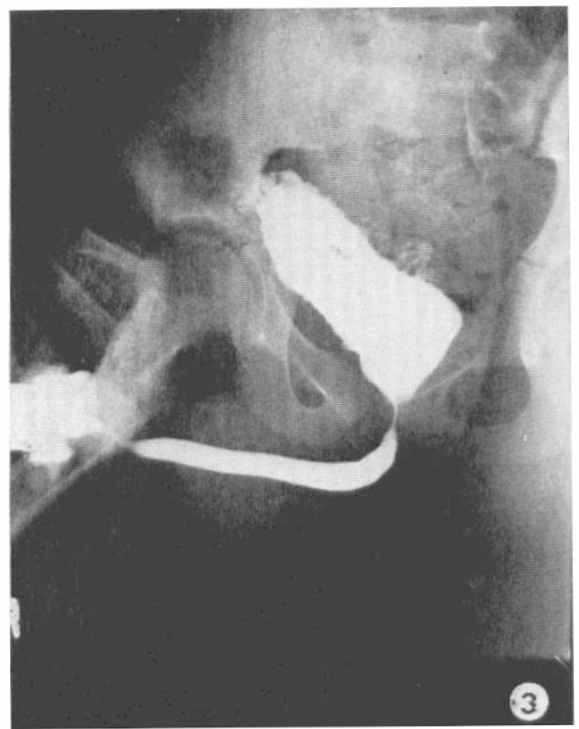

FIG. 3

Fig. 3.-Cysto-urethrography shows resistant external sphincter despite opening of bladder neck after Y-V plasty.

Fig. 4.-Descending cysto-urethrography. Good opening of the neck and relaxed external sphincter after T.U.R.

Fig. 5.-Retrograde cystogram. Massive V.U.R. with resistant sphincter.

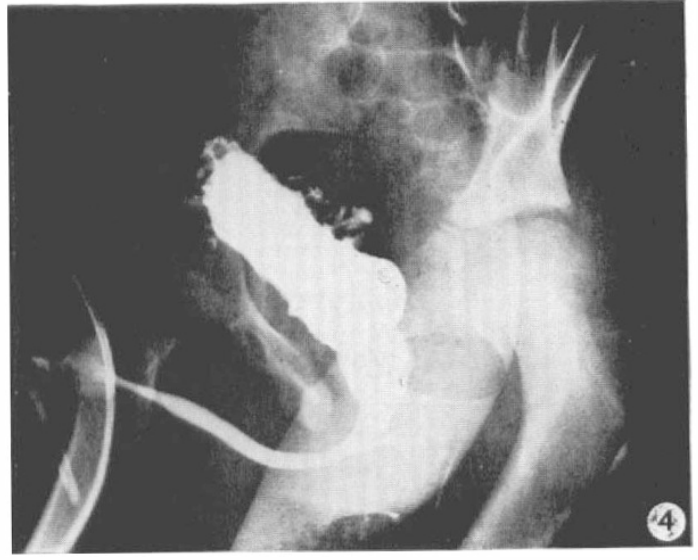

FIG. 4

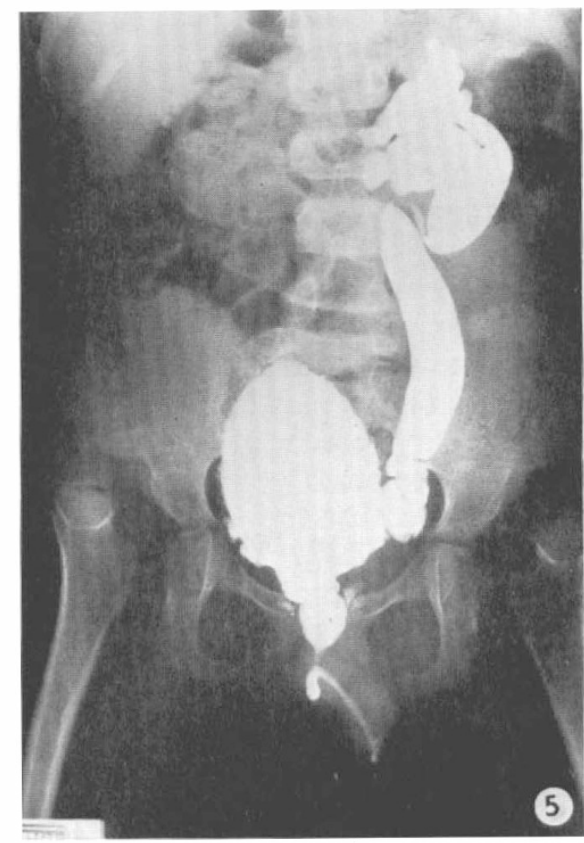

FIG. 5

According to these criteria, the bladder training by manual expression on the meningomyelocele bladder should be defined to those who have relaxed sphincter, regardless of the tonicity of detrusor muscle.

Hypotonicity of the detrusor muscle would be helped by oral administration of cholinergic drugs. It may also be possible to replace the resistant bladder outlet to the relaxed sphincter by surgical procedures (figs. 3 and 4 ). 


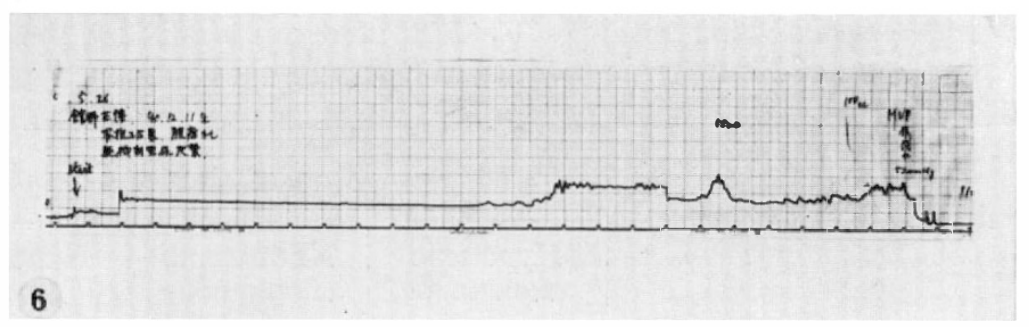

Fig. 6

Retrograde cystometrogram. Normotonic autonomous bladder.

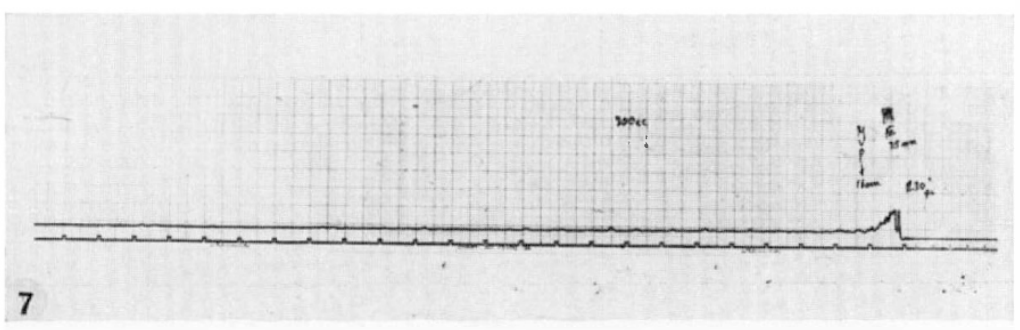

FIG. 7

Retrograde cystometrogram. Hypotonic autonomous bladder.

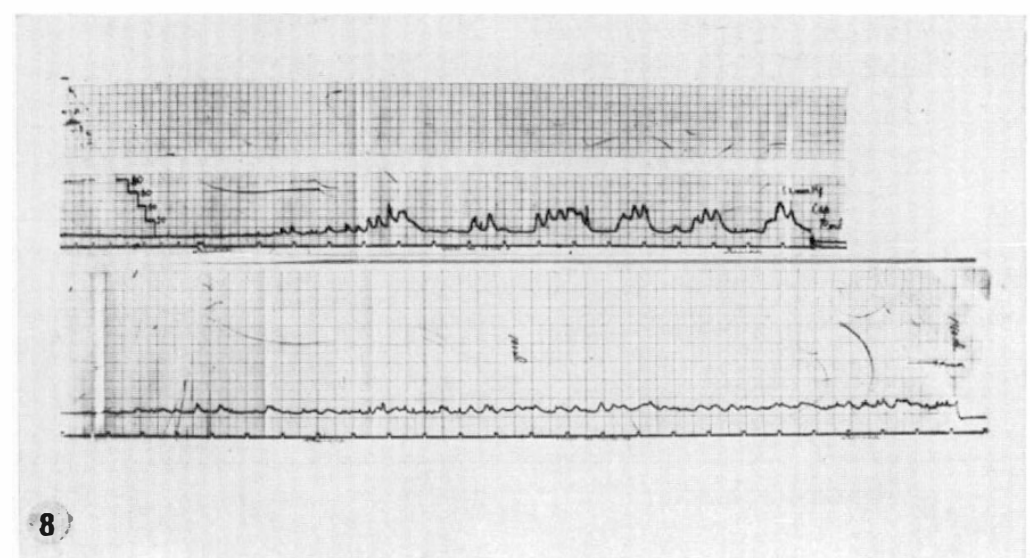

FIG. 8

Retrograde cystometrograms. Upper: Hypertonic spastic bladder before operation on the meningomyelocele. Lower: Hypotonic autonomous bladder after operation.

Actual harm by bladder expression may occur in cases with complete vesicoureteral refluxes which afflict the renal parenchyma by back-pressure. There are only I 6 cases which could be trained by manual expression according to these criteria. 
TABLE III

State of Neurogenic Bladder in Spina Bifida Cystica

\begin{tabular}{|l|c|c|c|c|}
\hline Lesion & Sphincter & \multicolumn{3}{|c|}{ Type of bladder } \\
\cline { 2 - 5 } & $\begin{array}{c}\text { Hypotonic } \\
\text { autonomous }\end{array}$ & $\begin{array}{c}\text { Normotonic } \\
\text { autonomous }\end{array}$ & $\begin{array}{c}\text { Hypertonic } \\
\text { spastic }\end{array}$ \\
\hline Lumbo-sacral & $\begin{array}{c}\text { Relaxed } \\
\text { sphincter } \\
\text { Sphincteric } \\
\text { resistance }\end{array}$ & 5 & 4 & I \\
\hline Sacral & $\begin{array}{c}\text { Relaxed } \\
\text { sphincter } \\
\text { Sphincteric } \\
\text { resistance }\end{array}$ & 6 & 7 & 0 \\
\hline Total & 7 & 2 & 0 \\
\hline
\end{tabular}

TABLE IV

Incidence of V.U.R. (Hydronephrosis) in Spina Bifida Cystica

\begin{tabular}{|c|c|c|c|}
\hline \multirow{2}{*}{ Lesion } & \multirow{2}{*}{ Sphincter } & \multicolumn{2}{|c|}{ Type of bladder } \\
\hline & & Hypotonic autonomous & Normotonic autonomous \\
\hline \multirow[t]{2}{*}{ Lumbo-sacral } & Relaxed sphincter & $0(0)$ & $0(0)$ \\
\hline & $\begin{array}{l}\text { Sphincteric } \\
\text { resistance }\end{array}$ & $0(0)$ & $2(I)$ \\
\hline \multirow[t]{2}{*}{ Sacral } & Relaxed sphincter & $2(\mathrm{I})$ & $0(0)$ \\
\hline & $\begin{array}{l}\text { Sphincteric } \\
\text { resistance }\end{array}$ & $5(5)$ & I (I) \\
\hline Total & & $7(6)$ & $3(2)$ \\
\hline
\end{tabular}

Adapting to these conditions, young children are trained in every 2-3 hours by manual expression by nurses or parents, habituating to perform the same training voluntarily on a stool in elder children. Figure 2 shows the effect of bladder training upon the reducing of residual urine in the children who have 
never been trained. Effects on bacterial counts and leucocytes in urine after bladder training were not always remarkable, despite considerable decreases in volume of residual urine.

The incidence of V.U.R. in spina bifida cystica is highest in cases with sacral lesion and hypotonic detrusor activity accompanied with sphincteric resistance, all of which revealed the hydronephrosis (Table IV).

\section{TABLE V}

Incidence of V.U.R. (Hydronephrosis) in Congenital Sacral Defects

\begin{tabular}{|l|c|c|}
\hline \multicolumn{1}{|c|}{ Lesion } & \multicolumn{2}{|c|}{ Type of bladder } \\
\hline Agenesis (2 cases) & Hypotonic autonomous & Normotonic autonomous \\
\hline Partial defect (5 cases) & $2(2)$ & $0(0)$ \\
\hline Total & $3(0)$ & $0(0)$ \\
\hline $5(0)$ & $0(0)$ \\
\hline
\end{tabular}

Also, it is so characteristic that all cases with V.U.R. in sacral defects or agenesis have hypotonic autonomous activity of the detrusor muscle (Table V).

We have not yet performed many surgical approaches to the dysfunctioned bladder and the deteriorated upper urinary tract, as the period of observation is not long enough (Table VI).

\section{TABLE VI}

Surgical Procedures to Upper Urinary Tract Deterioration in Children with Spina Bifida Cystica and Sacral Defect

\begin{tabular}{|c|c|c|c|}
\hline & & Good effect & Poor effect \\
\hline Temporary cystotomy & I & I & - \\
\hline T.U.R. & 2 & 2 & - \\
\hline Uretero-cysto-anastomosis & I & - & I \\
\hline Y-V plasty & 2 & I & I \\
\hline Tubeless ureterostomy & 3 & I & 2 \\
\hline
\end{tabular}

I think more surgical procedures in adequate time would be helpful for the habilitation of these disabled children.

It is an embarrassing problem for us that the parents of these children would not fully appreciate the urological complications and hesitate to give consensus for surgery which tends to delay adequate chance for surgical repair. 